\title{
Pengaruh Efektivitas SIA, Kecanggihan Teknologi Informasi, dan Kemampuan Teknik Pemakai SIA pada Kinerja Individu
}

\author{
Luh Putu Radhakrishnan Dewi ${ }^{1}$ \\ Ida Bagus Dharmadiaksa ${ }^{2}$ \\ ${ }^{1,2}$ Fakultas Ekonomi dan Bisnis Universitas Udayana (Unud), Bali, Indonesia \\ e-mail: radhakrishnan547@yahoo.com
}

\begin{abstract}
ABSTRAK
Tujuan dari penelitian ini adalah untuk memeroleh bukti empiris mengenai pengaruh efektivitas sistem informasi akuntansi, kecanggihan teknologi informasi, dan kemampuan teknik pemakai sistem informasi akuntansi pada kinerja individu. Penelitian ini dilakukan pada 27 Bank Perkreditan Rakyat di Kabupaten Gianyar. Jumlah sampel yang diambil adalah sebanyak 108 responden dengan metode penetuan sampel yaitu metode sampel jenuh. Pengumpulan data dilakukan dengan cara penyebaran kuesioner, dokumentasi dan wawancara. Teknik analis data yang digunakan adalah teknik analisis regresi linier berganda. Hasil penelitian ini menunjukkan bahwa efektivitas sistem informasi akuntansi, kecanggihan teknologi informasi, dan kemampuan teknik pemakai sistem informasi akuntansi berpengaruh positif pada kinerja individu.
\end{abstract}

Kata kunci: Efektivitas SIA, kecanggihan TI, kemampuan teknik pemakai SIA,

kinerja individu

\begin{abstract}
The purpose of this study is to obtain empirical evidence regarding the effect of the effectiveness of accounting information systems, the sophistication of information technology, and the technical ability users of accounting information systems of individual performance. This research was conducted on 27 BPR in Gianyar Regency. The number of samples taken is 108 respondents with the method of determining the sample, namely the saturated sample method. Data collection is done by distributing questionnaires, documentation and interviews. The data analysis technique used is multiple linear regression analysis techniques. The results of this study indicate that the effectiveness of accounting information systems, the sophistication of information technology, and the technical ability users of accounting information systems have a positive effect of individual performance.
\end{abstract}

Keywords: Effectiveness AIS, sophistication IT, technical ability users AIS, individual performance.

\section{PENDAHULUAN}

Perkembangan dan kecanggihan teknologi informasi pada masa ini terus mengalami kemajuan seiring dengan perkembangan sistem informasi berbasis teknologi pula. Berkembangnya teknologi informasi akan memermudah kinerja dan memungkinkan berbagai kegiatan dapat dilaksanakan dengan cepat, tepat dan 
akurat, sehingga akhirnya akan meningkatkan produktivitas suatu organisasi atau individu. Teknologi informasi terus berkembang salah satu hasil pengembangan teknologi informasi yang banyak dimanfaatkan oleh organisasi untuk menjalankan kegiatan operasionalnya adalah sistem informasi. Teknologi informasi adalah perpaduan antara beberapa teknologi berbasis komputer dan telekomunikasi, seperti perangkat keras, perangkat lunak, teknologi jaringan, database, dan peralatan telekomunikasi lainnya (Gunawan dan Tenaya, 2017). Teknologi informasi bisa dikatakan sebagai penunjang penerapan sistem informasi dan berpengaruh juga terhadap kinerja individu.

Kinerja individu mengacu pada prestasi kerja individu yang diatur berdasarkan standar atau kriteria yang telah ditetapkan oleh suatu organisasi. Kinerja individu sangat memengaruhi keberhasilan sebuah perusahaan, diharapkan individu dapat menyelesaikan tugasnya tepat waktu dengan sistem yang ada. Kinerja individu dapat memengaruhi tingkat keberhasilan suatu pekerjaan karena dengan hasil yang dicapai tersebut dapat mengetahui seberapa besar hasil kinerja seorang individu tersebut. Berdasarkan salah satu fenomena yang terjadi di Bank Perkreditan Rakyat Kabupaten Gianyar yang bersumber dari Majalah Infobank yaitu majalah portal berita seputar perbankan dan keuangan, menyatakan bahwa pada tahun 2015 seluruh BPR yang berada di Kabupaten Gianyar masuk dalam kategori "Sangat Bagus". BPR yang dikategorikan sangat bagus adalah BPR yang memiliki kinerja baik yaitu memiliki total aset di atas Rp 1.000.000.000. 
Selain itu, kategori tersebut juga diukur dari berbagai aspek yang meliputi kualitas kredit, keberhasilan menghimpun dana pihak ketiga, penyaluran kredit, presentase laba serta kemampuan penggunaan sistem informasi akuntansi. Semua aspek tersebut tergantung dengan teknologi informasi dan sistem informasi akuntansi. Apabila dalam pemanfaatan teknologi informasi dan sistem informasi akuntansi dilakukan secara baik dan sesuai dengan peraturan yang ada, maka segala aspek tersebut akan terpenuhi. Apalagi menurut majalah Infobank, pihak Otoritas Jasa Keuangan (OJK) tengah menggodok Peraturan Otoritas Jasa Keuangan (POJK) baru terkait sistem teknologi informasi (IT) bagi Bank Perkreditan Rakyat (Yoga, 2016). Hal tersebut akan membantu tercapainya kategori BPR sangat bagus. Peran serta teknologi informasi dan sistem informasi akuntansi sangat menunjang perkembangan kinerja keuangan dan kinerja individu pada BPR di Kabupaten Gianyar. Maka dari itu teknologi informasi dan sistem informasi akuntansi tidak bisa dijauhkan dengan segala kegiatan keuangan di lembaga keuangan salah satunya BPR.

Keberhasilan sebuah perusahan bisa dilihat dari kinerja seorang individu dalam memanfaatkan teknologi sistem informasi untuk memberikan kemudahan bagi mereka dalam menyelesaikan tugasnya, yang pada akhir berdampak pada peningkatan kinerja perusahan itu sendiri. Sistem informasi akuntansi merupakan variabel paling memengaruhi kinerja keuangan (Soudani, 2012). Sistem informasi akuntansi ini merupakan sebuah peluang khususnya bagi para pebisnis dalam rangka optimalisasi efisiensi dan efektivitas dalam pengambilan keputusan sehingga memungkinkan perusahaan 
memeroleh keunggulan kompetitif (Edison et al, 2012). Efektivitas sistem informasi akuntansi mengukur sejauh manatarget yang dicapai dari suatu kumpulan sumber daya yang diatur untuk mengumpulkan, memproses, dan menyimpan data elektronik. Kemudian diolah menjadi sebuah informasi yang berguna dan menyajikan laporan formal yang diperlukan dengan baik secara kualitas maupun waktu, yang pada akhirnya akan digunakan dalam pengambilan keputusan bagi sebuah perusahan.

Keberhasilan kinerja individu sangat dipengaruhi faktor kecanggihan teknologi informasi. Kecanggihan teknologi informasi kini berkembang pesat dengan jenis teknologi yang beragam. Keberagaman teknologi tersebut dapat memudahkan pengguna dalam mengimplementasikan tujuannya. Menurut (Hafeez-baig dan Gururajan, 2011) teknologi informasi merupakan salah satu sarana untuk meningkatkan kinerja perusahaan dan bisnis. Akuntansi sebagai bisnis, sistem bahasa dan informasi, harus menyesuaikan diri dengan teknologi baru yang akan disampaikan kepada pengguna laporan keuangan (Sarokolaei et al, 2012). Teknologi informasi dikatakan dapat membantu UKM dalam menyediakan infrastruktur yang diperlukan untuk menyediakan informasi yang tepat bagi penggunanya (Ghobakhloo et al, 2012). Ismail dan King (2007) mengatakan perusahaan yang memiliki kecanggihan teknologi memiliki tingkat keselarasan SIA yang baik dibandingkan dengan yang tidak menggunakan.

Kemampuan untuk mengelola informasi secara efektif di dalam perusahaan sangat penting karena dapat menjadi dasar untuk memeroleh keunggulan kompetitif (Maamir dan Yadnyana, 2012). Penggunaan teknologi 
informasi diperlukan kemampuan teknik pemakai, jika kemampuan teknik pemakai yang dimiliki suatu individu tinggi maka akan memermudah penggunaan suatu sistem, khususnya sistem informasi akuntansi. Penggunaan sistem informasi akuntansi dalam suatu organisasi yang didukung oleh meningkatnya kemampuan teknik pemakai akan membuat sistem informasi dapat berjalan denga efektif dan mampu meningkatkan kinerja organisasi atau individu itu sendiri.Sistem informasi akuntansi berbasis komputer kini mulai digunakan oleh semua organisasi tidakterkecuali lembaga keuangan.Bank Perkreditan Rakyat.

Berdasarkan penelitian terdahulu, masih terdapat perbedaan-perbedaan hasil penelitian.Pratiwi dan Dharmadiaksa (2018) mengungkapkan bahwa efektivitas sistem informasi akuntansi berpengaruh positif terhadap kinerja individu di BPR yang tersebar di Kabupaten Badung, begitu pula sama dengan penelitian (Gunawan dan Tenaya, 2017). Selain itu penelitian yang dilakukan oleh (Saifulloh, 2016) dan (Alannita dan Suaryana, 2014) menyatakan bahwa kecanggihan teknologi informasi berpengaruh positif terhadap kinerja individu. (Dewi dan Dharmadiaksa, 2017) menyatakan bahwa kemampuan teknis pemakai sistem informasi akuntansi berpengaruh positif terhadap kinerja individu. Namun sebaliknya disisi lain juga terdapat penelitian yang menunjukan bahwa pemakaian sistem informasi akuntansi tidak dapat meningkatkan profitabilitas, kinerja individu, dan efisiensi operasi seperti pada penelitian (Grande et al, 2011), (Kouser et al, 2016) dan (Kharuddin, 2010). (Soudani, 2012) juga menemukan hasil penelitian yang menunjukan hasil yang tidak mendukung adanya hubungan yang positif antara sistem informasi akuntansi pada kinerja individu. 
Berdasarkan perbedaan hasil penelitian tersebut, sehingga diteliti kembali dengan mereplikasi penelitian (Dewi dan Dharmadiaksa, 2017) tentang pengaruh efektivitas sistem informasi akuntansi, pemanfaatan teknologi informasi dan kemampuan teknik pemakai sistem informasi akuntansi pada kinerja individu di Koperasi Simpan Pinjam Kabupaten Karangasem. Perbedaan penelitian ini dengan penelitian terdahulu, yaitu penelitian ini mengganti variabel independen pemanfaatan teknologi informasi dengan kecanggihan teknologi informasi karena apabila suatu teknologi informasi belum canggih maka pemanfaatan terhadap teknologi informasi kurang efisien dan bisa disalahgunakan karena kurangnya keamanan pada teknologi informasi yang digunakan. Hal tersebut dibuktikan pada fenomena yang terjadi pada salah satu BPR di Kabupaten Gianyar yaitu BPR Suryajaya Ubud. Menurut artikel yang dikutip pada www.kumparan.com menyatakan bahwa salah satu username teller pada BPR Suryajaya yang berinisial NWPLD telah dibobol oleh pihak direksi sehingga terjadi penggelapan uang nasabah hingga mencapai nilai Rp 7,6 miliar (diunggah 30 Oktober 2018). Berdasarkan pertimbangan hal tersebut, maka akan dibuktikan pengaruh ketiga faktor tersebut pada kinerja individu. Judul yang diambil adalah "Pengaruh Efektivitas Sistem Informasi Akuntansi, Kecanggihan Teknologi Informasi dan Kemampuan Teknik Pemakai Sistem Informasi Akuntansi pada Kinerja Individu Bank Perkreditan Rakyat di Kabupaten Gianyar".

Berdasarkan latar belakang di atas, maka dapat dirumuskan beberapa rumusan masalah penelitian sebagai berikut: 1) Apakah efektivitas sistem informasi akuntansi berpengaruh positif terhadap kinerja individu?; 2) Apakah 
kecanggihan teknologi informasi berpengaruh positif terhadap kinerja individu?; 3) Apakah kemampuan teknik pemakaisistem informasi akuntansiberpengaruh positif terhadap kinerja individu?. Tujuan penelitian ini adalah untuk memeroleh bukti empirisefektivitas sistem informasi akuntansi, kecanggihan teknologi informasi, dan kemampuan teknik pemakai sistem infromasi akuntansi berpengaruh positif terhadap kinerja individu. Hasil penelitian ini diharapkan dapat memberikan manfaat teoritis yaitu diharapkan dapat memberikan sumbangan pengetahuanmengenai Teori Technology Acceptance Model sehingga nantinya dapat digunakan sebagai refrensi bagi penelitian lanjutan di masa mendatang dan manfaat praktis diharapkan dapat memberikan sumbangan pemikiran dan masukan bagi BPR di Kabupaten Gianyar untuk meningkatkan kinerja individunya.

Model penerimaan teknologi (Technology Acceptance Model) merupakan salah satu model yang dibangun untuk menganalisis dan memahami faktor- faktor yang memengaruhi diterimanya penggunaan teknologi komputer. TAM memiliki tujuan untuk dapat menjelaskan faktor-faktor utama perilaku pengguna teknologi informasi terhadap penerimaan pengguna teknologi informasi itu sendiri. Menurut (Venkatesh dan Morris, 2006) TAM digunakan untuk melihat pemahaman individual yang secara terus menerus menggunakan teknologi informasi dalam aktifitasnya. Penggunaan sistem informasi pada individu untuk melakukan aktivitas dan pemanmaatannya masih menjadi pehatian penting bagi peneliti, walaupun terdapat kemajuan yang cukup berarti dalam kemampuan hardware dan 
software. Tingginya penggunaan sistem informasi menandakan bermanfaat dan mudahnya suatu sistem informasi.

TAM adalah pengembangan TRA (Theory of Reason Action) dan diyakini mampu meramalkan penerimaan pemakai terhadap teknologi berdasarkan dampak dari dua faktor, yaitu perspektif kemanfaatan (perceived usefulness) dan perspektif kemudahan penggunaan (perceived ease of use) (Davis, 1989). Teori TAM mendukung variabel efektivitas sistem informasi akuntansi dengan menyatakan bahwa penggunaan sistem informasi akan meningkatkan kinerja individu atau perusahaan dan penggunaan sistem informasi akan memermudah pemakainya dalam menyelesaikan suatu pekerjaan (Gupta et al, 2007). Variabel kecanggihan teknologi informasi juga didukung oleh Teori TAM yang menyatakan bahwa setiap seseorang yang mengadopsi suatu teknologi baru, maka penggunaan teknologi akan dihadapkan oleh faktor-faktor yang memengaruhi individu untuk menggunakan teknologi tersebut salah satunya kinerja individu itu sendiri. Teori TAM juga mendukung variabel kemampuan teknik pemakai sistem informasi yang berasumsi bahwa seseorang yang mengadopsi suatu teknologi pada umumnya bertujuan untuk memuaskan pemakainya atau memaksimalkan kemampuan dan kegunaan sistem teknologi informasi itu sendiri agar tercapainya kinerja yang optimal. Ketiga variabel pada penelitian ini didukung oleh Teori TAM.

Sistem adalah kelompok dari dua atau lebih komponen atau subsistem yang saling berhubungan yang berfungsi dengan tujuan yang sama (Hall, 2008).Menurut (Nwokeji, 2012) sistem akan memproses data dan mengubah 
mereka menjadi informasi akuntansi selama input, proses dan output tahap yang akan digunakan oleh berbagai pengguna internal dan eksternal. Informasi yang berkualitas berperan penting untuk pengelolaan setiap organisasi menjadi dasar atas kegiatan usaha individu (Nwokeji, 2012). Menurut Bodnar dan Hopwood (2006:3), informasi adalah suatu data yang diorganisasi yang dapat medukung ketepatan pengambilan keputusan.

Menurut, Jogiyanto (2000:49), sistem informasi akuntansi merupakan gabungan dari manusia dan sumber daya lainnya yang bertanggungjawab dalam menyediakan informasi keuangan serta informasi yang diperoleh melalui pengumpulan dan pengolahan data transaksi dalam suatu organisasi, sedangkan Bodnar dan William (2006:1) mendefinisikan sistem informasi akuntansi sebagai komponen sumber daya yang digunakan untuk mengolah data menjadi informasi yang berguna.

Berdasarkan pengertian di atas sistem informasi akuntansi adalah gabungan sumber daya yang berguna mengumpulkan dan mengolah suatu data menjadi indormasi yang dibutuhkan untuk mengambil keputusan.

Menurut (Mollanazari dan Abdolkarimi, 2012), sistem informasi berbasis komputer adalah komputer yang memproses transaksi keuangan dan transaksi non-keuangan dan dukungan tugas keputusan dalam konteks koordinasi dan pengendalian kegiatan organisasi. Sistem informasi berbasis komputer memiliki lima komponen yaitu input, proses, penyimpanan, output dan pengendalian internal dan berlaku di bawah kondisi kepastian, resiko dan ketidakpastian. Menurut Turban et al., (2006:49), sistem informasi berbasis komputer (computer- 
based information system- CBIS) adalah sistem informasi yang menggunakan teknologi computer untuk melakukan beberapa atau seluruh pekerjaan yang diberikan.

Secara umum, efektivitas diartikan sebagai alat ukurtercapainya kesuksesan atas tujuan yang ditetapkan. Menurut Siagian (2001:24), efektivitas merupakan sumber daya, sarana, dan prasarana yang digunakan pada jumlah yang telah ditentukan untuk menghasilkan barang atas jasa kegiatan yang dilaksanakan. Efektivitas sistem didasarkan pada kontribusi dalam pembuatan keputusan, kualitas informasi akuntansi, evaluasi kinerja, pengendalian internal yang memfasilitasi transaksi perusahaan (Sajady et al, 2008).

Efektivitas suatu sistem informasi akuntansi yaitu ukuran yang memberikan kontribusi dalam pembuatan keputusan melalui suatu kumpulan sumber daya yang dikumpulkan, diproses dan disimpan dalam data elektronik, yang kemudian diubah menjadi suatu informasi yang dapat berguna, pengukuran efektivitas teknologi sistem informasi akuntansi, antara lain: kualitas informasi, kualitas sistem, kualitas jasa, kegunan sistem, kepuasan pengguna dan keuntungan bersih (Kharisma dan Dharmadiaksa, 2015).

Teori TAMdiyakini mampu meramalkan penerimaan pemakai terhadap teknologi berdasarkan dampak dari dua faktor, yaitu perspektif kemanfaatan (perceived usefulness) dan perspektif kemudahan penggunaan (perceived ease of use) (Davis, 1989). Menurut (Venkatesh dan Morris, 2006) TAM digunakan untuk melihat pemahaman individual yang secara terus menerus menggunakan 
teknologi informasi dalam aktifitasnya. Teori TAM mengadopsi Theory of Reason Action (TRA) dari (Fishbein dan Ajzen, 2014) yang digunakan untuk melihat tingkat penggunaan responden dalam menerima teknolog informasi. Teori Technology Acceptance Model menjelaskan bahwa sistem informasi yang digunakan secara tepat dapat meningkatkan kinerja individu dan organisasi (Gupta et al, 2007). (Suratini dkk, 2015) menyatakan bahwa tingkat efektivitas sistem informasi akuntansi berpengaruh positif dan signifikan terhadap kinerja individu dan karyawan. Berdasarkan uraian tersebut, maka dapat dirumuskan hipotesis sebagai berikut.

$\mathrm{H}_{1}$ : Efektivitas sistem informasi akuntansi berpengaruh positif terhadap kinerja individu Bank Perkreditan Rakyat di Kabupaten Gianyar.

Teori Technology Acceptance Model menyatakan bahwa ketika terdapat suatu teknologi baru, maka penggunaan teknologi akan dihadapkan oleh faktorfaktor yang memengaruhi individu untuk menggunakan teknologi tersebut salah satunya kinerja individu itu sendiri. (Alannita dan Suaryana, 2014) dan (Rokhani, 2017) menyatakan kecanggihan teknologi informasi berpengaruh signifikan terhadap kinerja individu. Berdasarkan uraian tersebut, maka dapat dirumuskan hipotesis sebagai berikut.

$\mathrm{H}_{2}$ : Kecanggihan teknologi informasi berpengauh positif terhadap kinerja individu Bank Perkreditan Rakyat di Kabupaten Gianyar.

Teori Technology Acceptance Model berasumsi bahwa seseorang mengadopsi suatu teknologi pada umumnya bertujuan untuk memuaskan pemakainya atau memaksimalkan kemampuan atau kegunaan sistem teknologi informasi itu sendiri agar tercapainya kinerja yang optimal. Kecanggihan 
fungsional pengguna memiliki pengaruh positif terhadap sistem informasi akuntansi (Al-eqab dan Ismail, 2011). (Dewi dan Dharmadiaksa, 2017) menyatakan terdapat hubungan positif antara kemampuan teknik pemakasi sistem informasi akuntansi pada kinerja individu. Berdasarkan penjelasan diatas, maka rumusan hipotesis yang digunakan adalah:

$\mathrm{H}_{3}$ : Kemampuan teknik pemakai sistem informasi akuntansi berpengaruh positif pada kinerja individu Bank Perkreditan Rakyat di Kabupaten Gianyar.

\section{METODE PENELITIAN}

Penelitian ini menggunakan pendekatan kuantitatif berbentuk asosiatif. Lokasi penelitian ini dilakukan di 27 BPR di Kabupaten Gianyar. Obyek penelitian pada penelitian ini yaitu mengenai efektivitas sistem informasi akuntansi, kecanggihan teknologi informasi, kemampuan teknik pemakasi sistem informasi akutansi padakinerja individu. Variabel independen penelitian ini adalah efektivitas sistem informasi akuntansi $\left(\mathrm{X}_{1}\right)$, kecanggihan teknologi informasi $\left(\mathrm{X}_{2}\right)$ dan kemampuan teknik pemakai sistem informasi akuntansi $\left(\mathrm{X}_{3}\right)$. Variabel dependen dalam penelitian ini adalah kinerja individu (Y). Indikator pengukuran variabel efektivitas sistem informasi akuntansi dalam (Delone dan Mclean, 1992) yaitusystem quality (kualitas sistem), information quality (kualitas informasi), service quality (kualitas layanan), information user (pengguna informasi), user satisfaction (kepuasan pengguna), dan net benefit (keuntungan pengguna) yang diadopsi dari (Dewi dan Dharmadiaksa, 2017). Kecanggihan Teknologi Informasi. Indikator pengukuran variabel kecanggihan teknologi informasi adalah sistem terkomputerisasi, jaringan komputer,jenis aplikasi yang digunakan, dan tingkat 
keamanan data yang diadopsi dari (Alannita dan Suaryana, 2014). Kemampuan teknik pemakai sistem informasi akuntansi dinilai berdasarkan tiga indikator, yaitu pengetahuan, kemampuan dan keahlian yang diadopsi dari (Dewi dan Dharmadiaksa, 2017). Indikator pengukuran kinerja individu yang menurut (Dwijayanthi dan Dharmadiaksa, 2013) yaitu kuantitas kerja, kualitas kerja, efisiensi karyawan, pemenuhan standar operasional perusahaan, dan ketepatan waktu pelaksana kerja.

Populasi dalam penelitian ini adalah seluruh Bank Perkreditan Rakyat di Kabupaten Gianyar, yaitu sebanyak 27 BPR. Metode penentuan sampel yang digunakan dalam penelitian ini adalah non probability sampling yaitu dengan metodesampel jenuh.maka sampel pada penelitian ini sebanyak 27 Bank Perkreditan Rakyat di Kabupaten Gianyar.Metode pengumpulan data yang digunakan dalam penelitian ini adalah kuesioner, dokumentasi, dan wawancara

\section{HASIL DAN PEMBAHASAN}

Pengujian instrumen penelitian terdiri dari menguji validitas dan reliabilitas instrumen. Semua indikator pernyataan dalam semua variabel yaitu kinerja individu, efektivitas sistem informasi akuntansi, kecanggihan teknologi informasi, dan kemampuan teknik pemakai sistem informasi akuntansi memiliki koefisien korelasi yang lebih besar dari 0,3. Jadi seluruh indikator dapat dikatakan valid atau telah memenuhi syarat validitas data. Seluruh instrumen penelitian yang digunakan yaitu variabel kinerja individu, efektivitas sistem informasi akuntansi, kecanggihan teknologi informasi, dan kemampuan teknik pemakai sistem 
informasi akuntansi memiliki koefisien cronbach alpha lebih besar dari 0,6 sehingga dapat disimpulkan bahwa pernyataan pada kuesioner tersebut reliabel.

Tabel 1.

Statistik Deskriptif

\begin{tabular}{lccccc}
\hline \multicolumn{1}{c}{ Variabel } & N & Minimum & Maksimum & Mean & $\begin{array}{c}\text { Standar } \\
\text { Deviasi }\end{array}$ \\
\hline Efektivitas SIA $\left(\mathrm{X}_{1}\right)$ & 108 & 13 & 24 & 18,76 & 2,38 \\
Kecanggihan TI $\left(\mathrm{X}_{2}\right)$ & 108 & 8 & 16 & 12,99 & 1,75 \\
Kemampuan Teknik & 108 & 6 & 12 & 9,31 & 1,44 \\
Pemakai SIA $\left(\mathrm{X}_{3}\right)$ & 108 & 11 & 20 & 16,08 & 1,98 \\
Kinerja Individu (Y) & & & & &
\end{tabular}

Berdasarkan Tabel 1 diperoleh nilai minimum dari jumlah skor jawaban responden untuk variabel efektivitas sistem informasi akuntansi $\left(\mathrm{X}_{1}\right)$ sebesar 13 karena salah satu responden menyatakan tidak setuju pada indikator kualitas sistem, kualitas layanan, pengguna informasi, kepuasaan pengguna dan keuntungan pengguna, sedangkan menyatakan setuju pada indikator kualitas informasi. Nilai maksimum variabel efektivitas sistem informasi akuntansi sebesar 24 karena empat responden menyatakan sangat setuju pada keenam indikator. Nilai rata-rata 18,76 menunjukkan bahwa responden dalam wilayah pernyataan pada kuesioner cenderung merasa setuju pada masing-masing item pernyataan, artinya efektivitas sistem informasi akuntansi cenderung tinggi. Standar deviasi pada variabel efektivitas sistem informasi akuntansi sebesar 2,38, berarti perbedaan tingkat efektivitas sistem informasi akuntansi yang diteliti terhadap nilai rata-ratanya sebesar 2,38.

Berdasarkan Tabel 1 diperoleh nilai minimum dari jumlah skor jawaban responden untuk variabel kecanggihan teknologi informasi $\left(\mathrm{X}_{2}\right)$ sebesar 8 karena salah satu responden menyatakan tidak setuju pada keempat indikator. Nilai maksimum sebesar 16 karena sebanyak sepuluh responden menyatakan sangat 
setuju pada keempat indikator. Nilai rata-rata 12,99 menunjukkan bahwa responden dalam wilayah pernyataan pada kuesioner cenderung merasa setuju pada masing-masing item pernyataan, artinya kecanggihan teknologi informasi cenderung tinggi. Standar deviasi pada variabel kecanggihan teknologi informasi sebesar 1,75 , berarti perbedaan tingkat kecanggihan teknologi informasi yang diteliti terhadap nilai rata-ratanya sebesar 1,75 .

Berdasarkan Tabel 1 diperoleh nilai minimum dari jumlah skor jawaban responden untuk variabel kemampuan teknik pemakai sistem informasi akuntansi $\left(\mathrm{X}_{3}\right)$ sebesar 6 karena sebanyak tiga responden menyatakan tidak setuju pada ketiga indikator. Nilai maksimum sebesar 12 karena sebanyak 14 responden menyatakan sangat setuju pada tiap indikator. Nilai rata-rata 9,31 menunjukkan bahwa responden dalam wilayah pernyataan pada kuesioner cenderung merasa setuju pada masing-masing item pernyataan, artinya kemampuan teknik pemakai sistem informasi akuntansi cenderung tinggi. Standar deviasi pada variabel kemampuan teknik pemakai sistem informasi akuntansi sebesar 1,44, berarti perbedaan tingkat kemampuan teknik pemakai sistem informasi akuntansi yang diteliti terhadap nilai rata-ratanya sebesar 1,44 .

Berdasarkan Tabel 1 diperoleh nilai minimum dari jumlah skor jawaban responden untuk variabel kinerja individu (Y) sebesar 11 karena salah satu responden menyatakan setuju pada indikator kuantitas kerja, sedangankan menyatakan tidak setuju pada indikator kualitas kerja, efisiensi karyawan, pemenuhan SOP dan ketepatan waktu pelaksanaan kerja. Nilai maksimum sebesar 20 karena sebanyak lima responden menyatakan sangat setuju pada kelima 
indikator. Nilai rata-rata 16,08 menunjukkan bahwa responden dalam wilayah pernyataan pada kuesioner cenderung merasa setuju pada masing-masing item pernyataan, artinya kinerja individu cenderung tinggi. Standar deviasi pada variabel kinerja individu sebesar 1,98, berarti perbedaan tingkat kinerja individu yang diteliti terhadap nilai rata-ratanya sebesar 1,98 .

Uji normalitas bertujuan untuk menguji apakah dalam model regresi, variabel residunya mempunyai distribusi normal atau tidak normal. Untuk menguji apakah data yang digunakan normal atau tidak dapat dilakukan dengan menggunakan uji Kolmogorov-Smirnov. Jika Asymp. Sig (2-tailed) lebih besar dari level of significance 0,05 yang dipakai, maka dapat disimpulkan bahwa residual suatu data dikatakan terdistribusi secara normal. Hasil uji normalitas dapat dilihat pada Tabel 2 .

Tabel 2.

Hasil Uji Normalitas

\begin{tabular}{lc}
\hline \multicolumn{1}{c}{ Kolmogorov-Smirnov $Z$} & Unstandardized Residual \\
\hline $\mathrm{N}$ & 108 \\
Asymp. Sig. (2-tailed) & 0,156 \\
\hline Sumber: Data diolah, 2018
\end{tabular}

Hasil uji normalitas di atas menunjukkan koefisien Asymp. Sig. (2-tailed) sebesar 0,156 yang lebih besar dari 0,05. Hal ini berarti data dalam penelitian ini berdistribusi normal.

Uji multikolinearitas bertujuan untuk menguji apakah model regresi ditemukan adanya korelasi antara variabel bebas. Multikolinearitas dapat dilihat dari nilai tolerance atau Variance Inflation Factor (VIF). Jika nilai tolerance lebih besar dari $10 \%$ atau VIF kurang dari 10 maka dapat dikatakan model telah bebas 
dari masalah multikolinearitas. Hasil uji multikolinearitas dapat dilihat pada Tabel 3.

Tabel 3.

Hasil Uji Multikoliniearitas

\begin{tabular}{|c|c|c|}
\hline Variabel & Tolerance & VIF \\
\hline Efektivitas SIA (X1) & 0,457 & 2,190 \\
\hline Kecanggihan TI (X2) & 0,585 & 1,710 \\
\hline Kemampuan Teknik Pemakai SIA (X3) & 0,666 & 1,502 \\
\hline
\end{tabular}

Sumber: Data diolah, 2018

Berdasarkan Tabel 3 dapat diketahui bahwa seluruh variabel menunjukkan nilai tolerance lebih dari 0,10 dan nilai VIF yang kurang dari 10 . Hal ini mengidentifikasi bahwa dalam penelitian ini tidak terjadi multikolinearitas.

Uji heteroskedastistas bertujuan menguji apakah dalam model regresi terjadi ketidaksamaan variance dari residual satu pengamatan ke pengamatan lain. Uji heteroskedastistas dapat dianalisis melalui uji Glejser dengan melihat tingkat signifikansi berada di atas 0,05 maka model regresi bebas dari masalah heteroskedastistas. Hasil uji heteroskedastistas dapat dilihat pada Tabel 4.

Tabel 4.

Hasil Uji Heteroskedastistas

\begin{tabular}{|c|c|c|}
\hline Variabel & Signifikansi & Keterangan \\
\hline Efektivitas SIA $\left(\mathrm{X}_{1}\right)$ & 0,319 & Bebas \\
\hline & & Heteroskedastisitas \\
\hline Kecanggihan TI $\left(\mathrm{X}_{2}\right)$ & 0,671 & Bebas \\
\hline Kemampuan Teknik Pemakai SIA $\left(\mathrm{X}_{3}\right)$ & 0,068 & $\begin{array}{c}\text { Heteroskedastisitas } \\
\text { Bebas Heteroskedastisitas }\end{array}$ \\
\hline
\end{tabular}

Sumber: Data diolah, 2018

Berdasarkan Tabel 4 dapat dilihat bahwa hasil uji heteroskedastistas menunjukan bahwa nilai signifikansi pada masing-masing variabel lebih dari 0,05. Hal ini berarti model regresi yang digunakan bebas heteroskedastistas. 
Tabel 5.

Hasil Analisis Regresi Linier Berganda

\begin{tabular}{lccccc}
\hline \multicolumn{1}{c}{ Model } & \multicolumn{2}{c}{$\begin{array}{c}\text { Unstandarized } \\
\text { Coefficients }\end{array}$} & $\begin{array}{c}\text { Standardized } \\
\text { Coefficients }\end{array}$ & $\mathrm{t}$ & \multirow{2}{*}{ Sig. } \\
\cline { 2 - 4 } & $\mathrm{B}$ & Std. Error & Beta & & \\
\hline (Constant) & 3,833 & 1,148 & & 3,339 & 0,001 \\
Efektivitas $\left(\mathrm{X}_{1}\right)$ & 0,190 & 0,081 & 0,228 & 2,340 & 0,021 \\
Kecanggihan $\left(\mathrm{X}_{2}\right)$ & 0,210 & 0,097 & 0,186 & 2,165 & 0,033 \\
Kemampuan $\left(\mathrm{X}_{3}\right)$ & 0,640 & 0,111 & 0,466 & 5,776 & 0,000 \\
Adjusted $R$ Square & 0,536 & & & & \\
F Hitung & 42,163 & & & & \\
Signifikansi F & 0,000 & & & &
\end{tabular}

Berdasarkan hasil penelitian tersebut, maka model regresi linier berganda adalah:

$$
\mathrm{Y}=3,833+0,190 \mathrm{X}_{1}+0,210 \mathrm{X}_{2}+0,640 \mathrm{X}_{3}+e
$$

Persamaan regresi linier berganda tersebut dapat dijelaskan sebagai berikut. Nilai konstanta sebesar 3,833 apabila efektivitas sistem informasi akuntansi $\left(\mathrm{X}_{1}\right)$, kecanggihan teknologi informasi $\left(\mathrm{X}_{2}\right)$ dan kemampuan teknik pemakai sistem informasi akuntansi $\left(\mathrm{X}_{3}\right)$ bernilai 0 , maka nilai kinerja individu (Y) meningkat sebesar 3,833 satuan.Nilai efektivitas sistem informasi akuntansi $\left(\mathrm{X}_{1}\right)$ sebesar 0,190 apabila efektivitas sistem informasi akuntansi meningkat sebesar 1 satuan dengan asumsi bahwa variabel lainnya konstan, maka kinerja individu meningkat sebesar 0,190 satuan.Nilai kecanggihan teknologi informasi $\left(\mathrm{X}_{2}\right)$ sebesar 0,210 apabila kecanggihan teknologi informasi meningkat sebesar 1 satuan dengan asumsi bahwa variabel lainnya konstan, maka kinerja individu meningkat sebesar 0,210 satuan.Nilai kemampuan teknik pemakai sistem informasi akuntansi $\left(\mathrm{X}_{3}\right)$ sebesar 0,640 apabila kemampuan teknik pemakai sistem informasi akuntansimeningkat sebesar 1 satuan dengan asumsi bahwa variabel lainnya konstan, maka kinerja individu meningkat sebesar 0,640 satuan. 
Koefisien determinasi merupakan besarnya kontribusi variabel bebas terhadap variabel terikat. Koefisien determinasi yang digunakan adalah nilai dari adjusted $R^{2}$ karenanilai adjusted $R^{2}$ dapat naik ataupun turun apabila satu variabel ditambahkan ke dalam model. Berdasarkan Tabel 5, dapat dilihat nilai dari Adjusted $R$ Square adalah 0,536 atau 53,6 persen, ini berarti sebesar 53,6 persen variansi kinerja individu dapat dipengaruhi secara signifikan oleh variabel efektifitas sistem informasi akuntansi, kecanggihan teknologi informasi, dan kemampuan teknik pemakai sistem informasi akuntansi, sedangkan sisanya sebesar 46,4 persen dijelaskan oleh faktor-faktor lain yang tidak dijelaskan dalam model penelitian ini. Uji statistik $\mathrm{F}$ bertujuan untuk melihat apakah semua variabel independen yang dimaksud dalam model mempunyai pengaruh secara serempak terhadap variabel dependen. Hasil uji $\mathrm{F}$ dapat dilihat dari hasil olahan SPSS yaitu dengan membandingkan tingkat signifikansi $F$ hitung dengan $\alpha=0,05$. Apabila tingkat signifikansi $\mathrm{F}<\alpha=0,05$ maka hubungan antar variabel bebas adalah signifikan memengaruhi kinerja individu sebagai variabel terikat, sebaliknya jika tingkat signifikansi $\mathrm{F} \geq \alpha=0,05$ maka hubungan antar variabel bebas adalah tidak signifikan memengaruhi kinerja individu sebagai variabel terikat

Berdasarkan Tabel 5 dapat dilihat bahwa nilai signifikan uji $\mathrm{F}$ adalah sebesar 0,000 yang lebih kecil dari 0,05 atau 5 persen. Hal ini berarti bahwa model yang digunakan pada penelitian ini adalah layak uji. Hasil ini memberikan makna bahwa ketiga variabel independen yaitu efektifitas sistem informasi akuntansi, kecanggihan teknologi informasi, dan kemampuan teknik pemakai 
sistem informasi akuntansi tepat memprediksi atau menjelaskan fenomena kinerja individu.

Berdasarkan Tabel 5 dapat dilihat bahwa nilai tingkat signifikansi t untuk variabel efektivitas sistem informasi akuntansi sebesar 0,021 maka tingkat signifikansi $\mathrm{t}$ adalah $0,021<0,05$. Hal ini mengindikasikan hipotesis 1 yang menyatakan efektivitas sistem informasi akuntansi berpengaruh positif pada kinerja individu diterima $\left(\mathrm{H}_{1}\right.$ diterima).

Berdasarkan Tabel 5 dapat dilihat bahwa nilai tingkat signifikansi t untuk variabel kecanggihan teknologi informasi sebesar 0,033 maka tingkat signifikansi $\mathrm{t}$ adalah $0,033<0,05$. Hal ini mengindikasikan hipotesis 2 yang menyatakan kecanggihan teknologi informasi berpengaruh positif pada kinerja individu diterima $\left(\mathrm{H}_{2}\right.$ diterima).

Berdasarkan Tabel 5 dapat dilihat bahwa nilai tingkat signifikansi t untuk variabel kemampuan teknik pemakai sistem informasi akuntansi sebesar 0,000 maka tingkat signifikansi $\mathrm{t}$ adalah $0,000<0,05$. Hal ini mengindikasikan hipotesis 3 yang menyatakan kemampuan teknik pemakai sistem informasi akuntansi berpengaruh positif pada kinerja individu diterima $\left(\mathrm{H}_{3}\right.$ diterima).

Hasil uji parsial pengaruh efektivitas sistem informasi akuntansi $\left(\mathrm{X}_{1}\right)$ pada kinerja individu (Y) pada Tabel 5 diperoleh p-value sebesar 0,021 lebih kecil dari $\alpha=0,05$. Hal ini berarti efektivitas sistem informasi akuntansi berpengaruh signifikan terhadap kinerja individu. Nilai koefisien regresi efektivitas sistem informasi akuntansi $\left(\mathrm{X}_{1}\right)$ sebesar 0,19 menunjukan adanya pengaruh positif efektivitas sistem informasi akuntansi pada kinerja individu. Hasil ini menerima 
hipotesis $\mathrm{H}_{1}$ yang menyatakan efektivitas sistem informasi akuntansi berpengaruh positif pada kinerja individu. Pengaruh yang positif ini berarti terdapat hubungan yang searah antara efektivitas sistem informasi akuntansi dengan kinerja individu. Semakin tinggi tingkat efektivitas sistem informasi akuntansi, maka semakin tinggi kinerja individu. Bank Perkreditan Rakyat di Kabupaten Gianyar mampu menghasilkan sistem informasi akuntansi yang akurat, tepat waktu, lengkap, mudah dipahami, relevan dan menguntungkan bagi perusahaan yang nantinya dapat meningkatkan kinerja individu.

Hasil penelitian ini sesuai dengan penelitian yang dilakukan oleh (Pratiwi dan Dharmadiaksa, 2018), (Gunawan dan Tenaya, 2017), dan (Suryawan dan Suaryana, 2018)yang mengungkapkan bahwa efektivitas sistem informasi akuntansi berpengaruh positif dan signifikan terhadap kinerja individu. Sistem informasi akuntansi yang digunakan secara akurat, tepat waktu, dapat menguntungkan perusahaan maupun penggunanya dapat dikatakan efektif dan dapat meningkatkan kinerja individu. Hal tersebut didukung oleh Teori Technology Acceptance Model yang menyatakan bahwa penggunaan sistem informasi akan meningkatkan kinerja individu atau perusahaan, dan penggunaan sistem informasi akan memermudah pemakainya dalam menyelesaikan suatu pekerjaan (Gupta et al., 2007).

Hasil uji parsial pengaruh kecanggihan tenologi informasi $\left(\mathrm{X}_{2}\right)$ pada kinerja individu (Y) pada Tabel 5 diperoleh $p$-value sebesar 0,033 lebih kecil dari $\alpha=0,05$. Hal ini berarti kecanggihan tenologi informasi berpengaruh signifikan terhadap kinerja individu. Nilai koefisien regresi kecanggihan tenologi informasi 
$\left(\mathrm{X}_{2}\right)$ sebesar 0,21 menunjukan adanya pengaruh positif kecanggihan tenologi informasi pada kinerja individu. Hasil ini menerima hipotesis $\mathrm{H}_{2}$ yang menyatakan kecanggihan tenologi informasi berpengaruh positif pada kinerja individu. Pengaruh yang positif ini berarti terdapat hubungan yang searah antara kecanggihan tenologi informasi dengan kinerja individu. Semakin tinggi tingkat kecanggihan tenologi informasi, maka semakin tinggi kinerja individu. Bank Perkreditan Rakyat di Kabupaten Gianyar mampu mengimplementasikan teknologi informasi yang canggih dengan penggunaan sistem informasi akuntansi yang terkomputerisasi dan memiliki keamanan untuk melindungi kerahasiaan data dan informasi yang nantinya dapat meningkatkan kinerja individu.

Hasil penelitian ini sesuai dengan penelitian yang dilakukan oleh (Saifulloh, 2016) dan (Alannita dan Suaryana, 2014) yang menyatakan bahwa kecanggihan teknologi informasi berpengaruh positif dan signifikan terhadap kinerja individu. Teknologi informasi yang canggih dan dapat meningkatkan kinerja individu dalam menggunakan sistem informasi akuntansi suatu perusahaan, apabila memiliki sistem informasi akuntansi yang terkomputerisasi, telah menggunakan internet, memiliki aplikasi sistem informasi akuntansi, dan memiliki tingkat keamanan yang tinggi untuk menjaga data akuntansi atau keuangan. Teori Technology Acceptance Model menunjukkan bahwa ketika terdapat suatu teknologi baru, maka penggunaan teknologi akan dihadapkan oleh faktor-faktor yang memengaruhi individu untuk menggunakan teknologi tersebut salah satunya kinerja individu itu sendiri. 
Hasil uji parsial pengaruh kemampuan teknik pemakaiefektivitas sistem informasi akuntansi $\left(\mathrm{X}_{3}\right)$ pada kinerja individu $(\mathrm{Y})$ pada Tabel 5 diperoleh $p$-value sebesar 0,00 lebih kecil dari $\alpha=0,05$. Hal ini berarti kemampuan teknik pemakaiefektivitas sistem informasi akuntansi berpengaruh signifikan terhadap kinerja individu. Nilai koefisien regresi kemampuan teknik pemakai sistem informasi akuntansi $\left(\mathrm{X}_{3}\right)$ sebesar 0,64 menunjukan adanya pengaruh positif kemampuan teknik pemakai sistem informasi akuntansi pada kinerja individu. Hasil ini menerima hipotesis $\mathrm{H}_{3}$ yang menyatakan kemampuan teknik pemakai sistem informasi akuntansi berpengaruh positif pada kinerja individu. Pengaruh yang positif ini berarti terdapat hubungan yang searah antara kemampuan teknik pemakai sistem informasi akuntansi dengan kinerja individu. Semakin tinggi tingkat kemampuan teknik pemakai sistem informasi akuntansi, maka semakin tinggi kinerja individu. Bank Perkreditan Rakyat di Kabupaten Gianyar mampu menghasilkan kemampuan teknik pemakaisistem informasi akuntansi yang memiliki pengetahuan, kemampuan dan keahlian sistem informasi akuntansi yang nantinya dapat meningkatkan kinerja individu.

Hasil penelitian ini sesuai dengan penelitian yang dilakukan oleh (Dewi dan Dharmadiaksa, 2017) dan (Alannita dan Suaryana, 2014)yang menyatakan bahwa kemampuan teknik pemakai sistem informasi akuntansi berpengaruh positif dan signifikan terhadap kinerja individu. Individu yang memiliki kemampuan, pengetahuan dan keahlian mengenai sistem informasi akuntansi dalam menggunakan sistem tersebut akan membantu meningkatkan kinerja individu itu sendiri. Teori Technology Acceptance Model berasumsi bahwa 
seseorang mengadopsi suatu teknologi pada umumnya bertujuan untuk memuaskan pemakainya atau memaksimalkan kemampuan dan kegunaan sistem teknologi informasi itu sendiri agar tercapainya kinerja yang optimal.

Hasil penelitian ini secara teoritis dapat memberikan tambahan pengetahuan dan informasi mengenai pengaruh efektivitas sistem informasi akuntansi, kecanggihan teknologi informasi dan kemampuan teknik pemakai sistem informasi akuntansi pada kinerja individu. Terdapat bukti empiris antara efektivitas sistem informasi akuntansi, kecanggihan teknologi informasi dan kemampuan teknik pemakai sistem informasi akuntansi dengan kinerja individu. Hal tersebut didukung oleh teori Technology Acceptance Model (TAM) yang menjelaskan bahwa penggunaan sistem informasi akan meningkatkan kinerja individu atau perusahaan dan penggunaan sistem informasi akan memermudah pemakainya dalam menyelesaikan suatu pekerjaan (Gupta et al., 2007).

Hasil penelitian ini secara praktis dapat memberikan sumbangan pemikiran dan masukan bagi individu khususnya pada Bank Perkreditan Rakyat di Kabupaten Gianyar mengenai pengaruh efektivitas sistem informasi akuntansi, kecanggihan teknologi informasi dan kemampuan teknik pemakai sistem informasi akuntansi sehingga individu lebih professional dan dapat meningkatkan kinerjanya dengan mengetahui faktor-faktor yang memengaruhi kinerja individu dalam menjalankan tugasnya. 


\section{SIMPULAN}

Berdasarkan hasil analisis data dan pembahasan yang telah diuraikan pada bab sebelumnya, maka dapat ditarik simpulan sebagai berikut: 1) Efektivitas sistem informasi akuntansi berpengaruh positif pada kinerja individu Bank Perkreditan Rakyat di Kabupaten Gianyar. Semakin tinggi efektivitas sistem informasi akuntansi pada Bank Perkreditan Rakyat di Kabupaten Gianyar, dapat meningkatkan kinerja individu; 2) Kecanggihan teknologi informasi berpengaruh positif terhadap kinerja individu Bank Perkreditan Rakyat di Kabupaten Gianyar. Semakin tinggi kecanggihan teknologi informasi padaBank Perkreditan Rakyat di Kabupaten Gianyar, dapat meningkatkan kinerja individu; 3) Kemampuan teknik pemakai sistem informasi akuntansi berpengaruh positif pada kinerja individu Bank Perkreditan Rakyat di Kabupaten Gianyar. Semakin tinggi kemampuan teknik pemakai sistem informasi akuntansi pada Bank Perkreditan Rakyat di Kabupaten Gianyar, dapat meningkatkan kinerja individu.

\section{REFERENSI}

Al-eqab, M., \& Ismail, N. A. (2011). Contingency Factors and Accounting Information System Design in Jordanian Companies, (July). https://doi.org/10.5171/2011.166128

Alannita, N. P., \& Suaryana, I. G. N. A. (2014). Pengaruh Kecanggihan Teknologi Informasi, Partisipasi Manajemen, Dan Kemampuan Teknik Pemakai Sistem Informasi Akuntansi Pada Kinerja Individu. Akuntansi, 6, 33-45. Retrieved from https://ojs.unud.ac.id/index.php/Akuntansi/article/view/7777

Davis, F. D. (1989). Perceived Usefulness, Perceived Ease of Use, and User Acceptance of Information Technology, 13(3), 319-340.

Delone, W. H., \& Mclean, E. R. (1992). Information Systems Success: The Quest for the Dependent Variable, (4). 
Dewi, N. L. A. A., \& Dharmadiaksa, I. B. (2017). Pengaruh Efektivitas SIA, Pemanfaatan TI dan Kemampuan Teknis Pemakai SIA Terhadap Kinerja Individu, $18,386-414$.

Dwijayanthi, D. M., \& Dharmadiaksa, I. B. (2013). Pengaruh insentif, tingkat pendidikan, pelatihan dan pengalaman kerja pada kinerja individu pengguna sistem informasi akuntansi skpd dispenda kota denpasar, 2, 332-344.

Edison, G., Manuere, F., Joseph, M., \& Gutu, K. (2012). Evaluation Of Factors Influencing Adoption Of Accounting Information System By Small To Medium Enterprises In Chinhoyi, 1126-1141.

Fishbein, M., \& Ajzen, I. (2014). Attitudes and the Attitude-Behavior Relation: Reasoned and Automatic Processes, (June). https://doi.org/10.1080/14792779943000116

Ghobakhloo, M., Hong, T. S., Sabouri, M. S., \& Zulkifli, N. (2012). Strategies for Successful Information Technology Adoption in Small and Medium-sized Enterprises, 36-67. https://doi.org/10.3390/info3010036

Grande, E. U., Estebanez, R. P., \& Colomina, C. M. (2011). The impact of Accounting Information Systems ( AIS ) on performance measures: empirical evidence in Spanish SMEs The impact of Accounting Information Systems ( AIS ) on performance measures : empirical evidence in Spanish SMEs 1, (January). https://doi.org/10.4192/1577-8517-v11

Gunawan, I. M. P. A., \& Tenaya, A. I. (2017). Pengaruh Efektivitas Sistem Informasi AKuntansi pada Kinerja Individual dengan Kemampuan Teknik Personal Sebagai Pemoderasi, 20, 1621-1647.

Gupta, M. P., Kanungo, S., Kumar, R., \& Sahu, G. P. (2007). A Study of Information Technology Effectiveness in Select Government Organizations in India, 32(2), 7-21.

Hafeez-baig, A., \& Gururajan, R. (2011). Preliminary Study to Investigation the Determinants that Effect IS / IT, (November 2014).

Hall, J. A. (2008). Accounting Information Systems.

Ismail, N. A., \& King, M. (2007). Factors influencing the alignment of accounting information systems in small and medium sized Malaysian manufacturing firms, $1(1), 1-20$.

Kharisma, M. D., \& Dharmadiaksa, I. B. (2015). Pengaruh keterlibatan pengguna dan ukuran organisasi pada efektivitas penggunaan sistem informasi 
akuntansi, 3, 867-881.

Kharuddin, S. (2010). Information System and Firms 'Performance: The Case of Malaysian Small Medium Enterprises, 3(4), 28-35.

Kouser, R., Awan, A., Rana, G., \& Shahzad, F. A. (2016). Firm Size , Leverage And Profitability: Overriding Impact Of, (June).

Maamir, C. I., \& Yadnyana, I. K. (2012). Pengaruh Efektivitas Penggunaan dan Kepercayaan Pada Teknologi Sistem Informasi Terhadap Kinerja Individual di PT PLN ( Persero ) Distribusi Bali Area Pelayanan Denpasar, 1-34.

Mollanazari, M., \& Abdolkarimi, E. (2012). The Effects of Task , Organization and Accounting Information Systems Characteristics on the Accounting Information Systems Performance in Tehran Stock Exchange, 3(4).

Nwokeji, E. (2012). Repositioning Accounting Information System Through Effective Data Quality Management: A Framework For Reducing Costs And Improving Performance, 1(10), 86-94.

Pratiwi, L. P. E. A., \& Dharmadiaksa, I. B. (2018). E-Jurnal Akuntansi Universitas Udayana Pengaruh Pemanfaatan dan Relevansi Teknologi Informasi serta Efektivitas Sistem Informasi Akuntansi pada Kinerja Karyawan Fakultas Ekonomi dan Bisnis Universitas Udayana ( Unud ), Bali , Indonesia Fakultas Ekonomi da, 23, 351-378.

Rokhani, N. (2017). Pengaruh kecanggihan teknologi informasi, partisipasi manajemen, dan kemampuan teknik pemakai sistem informasi akuntansi terhadap kinerja individu.

Saifulloh, M. (2016). Pengaruh Kecanggihan Teknologi Informasi , Partisispasi Manajemen, Dan Kemampuan Teknik Pemakai Sistem Informasi Akuntansi Pada Kinerja Individu Pada Perusahaan Batik Brotoseno Sragen.

Sajady, H., Dastgir, M., \& Nejad, H. H. (2008). Evaluation of the Effectiveness of Accounting Information Systems, 6(2), 49-59.

Sarokolaei, M. A., Rahimipoor, A., Nadimi, S., \& Taheri, M. (2012). The investigating of barriers of development of e-banking in Iran, 62, 1100-1106. https://doi.org/10.1016/j.sbspro.2012.09.188

Soudani, S. N. (2012). The Usefulness of an Accounting Information System for Effective Organizational Performance, 4(5), 136-145. https://doi.org/10.5539/ijef.v4n5p136 
Suratini, N. P. E., Sinarwati, N. K., Wikrama, A., \& Atmadja, A. W. T. (2015). Penggunaan Teknologi Informasi Akuntansi Terhadap Kinerja Individual Pada Pt . Bank Pembangunan Daerah e-Journal S1 Ak Universitas Pendidikan Ganesha, 1(1).

Suryawan, I. K. I., \& Suaryana, I. G. N. A. (2018). Pengaruh Efektivitas Sistem Informasi Akuntansi Terhadap Kinerja Individual dengan Insentif Sebagai Variabel Pemoderasi Pada LPD. Pengaruh Efektivitas Sistem Informasi Akuntansi Terhadap Kinerja Individual Dengan Insentif Sebagai Variabel Pemoderasi Pada LPD, 23, 871-897.

Venkatesh, V., \& Morris, M. G. (2006). Why Don't Men Ever Stop to Ask For Directions? Gender, Social Influence and Their Role in Technology Acceptance and Usage Behavior.

Yoga, P. (2016). OJK Siapkan Aturan Soal IT BPR, 3-4. 